\title{
Linguistics and Translation of a Hungarian Holocaust Diary
}

\author{
Gabriel Mayer \\ University of Haifa-Holocaust Studies, Nahariya, Israel
}

\begin{abstract}
Éva Heyman started writing her diary on February 13,1944, Friday, on her 13th birthday. Three months later, on May 30, 1944, she was deported to Auschwitz and murdered there. Three days before her deportation, Éva was able to give the diary to the Hungarian family cook, who in turn, passed it on to Éva's mother, Ági Zsolt, two year later. The mother published the diary in Hungary in 1948, and almost 20 years later, in 1964, it appeared in Hebrew, published by Yad Vashem as one of the first diaries produced by this institution. The English translation was printed 10 years later, in 1974. Since the latter publication appeared, there has been a debate among scholars regarding the authenticity of the diary, especially because it remained in the hands of the mother and her husband, a well-known Hungarian writer Béla Zsolt, all these years. Some suspected that Zsolt might have had a part in refining the work to ensure its publishing success. The work has been out of print for decades, but less than two years ago, it was reprinted in its original Hungarian form in Budapest. The present case study compares the various versions and attempts to show that what appears, as having been altered by a renowned author is actually the result of a well-intentioned translation. The diaries contain some differences, attributable to translation, resulting in subtle alterations. Hungarian is a synthetic and therefore more laconic language than English. Even the best translation may inadvertently affect historiographical interpretation as well as the moral conclusions of the text. Moreover, the idiomatic structure of the average Hungarian's speech, and its simple, colloquial style present an additional challenge to direct translation. This diary may be a singular case of linguistic manipulation, but its implications are relevant on a much wider scale, especially when examining the writings of young victims. Alexandra Zapruder has pointed at a general tendency to elevate young victims' writings to a moral higher ground, specifically because of a desire to present them in a favorable light. Linguistic transmutation is a mechanism that may alter the original content and context. This paper wishes to draw attention to this device, especially when the original works are subjected to representation.
\end{abstract}

Keywords: Holocaust studies, linguistics, history, WWII (World War II), Transylvanian, holocaust, Genocide studies

\section{Introduction: The Diary and the Story of the Book}

Currently, the book that is out of print and difficult to find. There are several versions in three languages (Hungarian, Hebrew, and English), in the following order of appearance: 1948, 1964, 1974, and 1988. In 1964, Yad Vashem officially participated in the publication of the book (Hebrew and English versions), but three decades later, the doubt as to its authenticity, raised by Zapruder, is still unresolved (see the United States Holocaust Memorial Museum (USHMM) website). Today once again the original Hungarian version is

Gabriel Mayer, M.D., Department of Holocaust Studies, University of Haifa-Holocaust Studies.

Correspondence concerning this article should be addressed to Post Box 400, Nahariya, Israel. Email: gabe010@yahoo.com. 
available, and it can be analyzed in the light of Éva Heyman's character and the facts of her life.

\section{Scope of the Study}

The present study has two objectives. The first objective is to retell the story of Éva Heyman, from a vantage point reinforced by current Holocaust historiography, which allows us to take another look at this young girl's short life, within a general context of the period and of the life of Transylvanian Jewry. Transylvanian Jewry was caught up in the viciously effective Holocaust in Hungary, and in the last months of World War II (WWII) saw the largest number of deportations and murders - the most effective, best organized, and efficiently carried out murderous event of extermination of Jews, by both the Nazis and their Hungarian collaborators.

The second objective is to examine the life story of Éva Heyman, in a different light from that found in previous literature, which may advance the development of historiography. The story of the diary has its own historical significance, apart from the story of its main character: It expands the knowledge of key elements that post-WWII scholars consider when reconstructing the events of the Holocaust. The diary has been published in three languages over a period spanning 21 years, and underwent sufficient transformation to arouse suspicions of willful manipulation. Yet, a thorough investigation, which may reveal linguistic variations, may provide useful evidence for examination of the development of Holocaust historiography.

\section{The Story of Éva Heyman's Diary}

Dr. Judah Márton translated the original Hungarian version of the book, published in 1948, into Hebrew, and the translation was printed under the auspices of Yad Vashem in 1964; it was one of the first diaries that Yad Vashem published.

The English version (Hebrew-to-English translation by Moshe M. Kohn) was published by Yad Vashem and printed by Alpha Press in Jerusalem in 1974. It contains 124 pages, and includes a detailed introduction by this versions authorial included in this version by Dr. Márton, it should be noted that Dr. Márton lived for a few years in Nagyvárad and knew Éva's mother. This edition also features photographs interjected by the publishers. The original (Hungarian version) of her diary was given to the mother, Agnes Zsolt in 1945 by Mariska (the cook entrusted with it by Eva). In 1948, about three years later, Éva's mother, Ági Zsolt, published it. At least four more publications of the book followed. Describing the journey of the diary - from the hands of the author, Éva Heyman, to being hidden, found, and returned to her mother - preceding the multiple publications, may be considered a separate contribution to historiography.

Before going into a detailed discussion of the diary and of all the characters that figure in it, it is helpful to list the principal actors relevant to the story.

Éva Heyman turned 13 on Feb 13, 1944, and it was on this day that she started her diary, which she continued writing until May 30, 1944. Three days later, she was deported to Auschwitz, where she arrived on June 6, 1944, and where she was murdered on October 17, 1944. This information is noted in the book and well corroborated by multiple sources located at Yad Vashem and USHMM, among others. Éva's train transport number and dates are also available in Hungarian publications such as "A Native of Fugyivasarhely/Nagyvarad", a document available through the Tikvah Association, which still functions in Oradea (Nagyvarad) in today's Romania. 


\begin{tabular}{|c|l|c|c|}
\hline $\begin{array}{c}\text { TRANSPORT } \\
\text { NUMBER }\end{array}$ & & \multicolumn{1}{|c|}{ NAME OF STREET } & $\begin{array}{c}\text { DEPORTATION } \\
\text { DATE } \\
\text { 5704-1944 }\end{array}$ \\
\hline AURCHWITZ \\
5704-1944
\end{tabular}

Figure 1. Nagyvarad Deportation Schedule (compiled by Imre Reviczky, 1976).

The chain of transmission of the diary toward its publication deserves examination, which in turn warrants taking a look at the complicated history of Eva's family. Eva's mother, Ági, was married to Béla Heyman, an architect. When Éva was four years old, the couple divorced. Éva's father continued to live in Nagyvárad. Ági fell in love with Béla Zsolt, an important Hungarian writer, acclaimed both before and after the war.

Their passionate romance took them to various parts of Europe, from Paris to Budapest, while Éva was left in Nagyvárad, in the care of Ági's parents, the pharmacist Rácz, and his wife. Throughout the diary and in some related resources, the observations are made that for Éva's mother, Zsolt was the most important person in her life, and although she loved Éva and her own father, Rácz, very much, she would place her and Zsolt's wellbeing and survival first (contents located in a letter by Juzsti, found in the appendix of all editions). In the final day before deportation, the entire family was together in the ghetto, which was organized in four weeks. In the end, however, Ági and Béla managed to evade deportation by checking themselves in a hospital after successfully faking typhoid fever, whereas Éva and her grandparents were deported and murdered. The Zsolts eventually made it to Budapest and were included in the group known as "Kasztner's Train".

The other two people involved in the story are Juzsti, Éva's Austrian governess, who was also Ági's governess and thus a family member for all practical purposes, and Mariska Szabo, the Hungarian maid and cook. Both were involved with the family to the very end, paying occasional secret visits to the family. It was in Mariska's hands that Éva placed the diary three days before deportation, when they were being moved into the ghetto.

In 1945, when Ági returned to Nagyvárad, she met with Mariska, who preserved the diary and remitted it to her. Apparently, Ági waited for three years before publishing the diary in Budapest, in 1948. The original book includes an introduction by Ágnes Zsolt and an Appendix with two letters written to her. One, dated September 8, 1945, is from Mariska, notifying Ági that she has the diary, and the other one, dated November 21, 1945, is from Juzsti, containing a summary of the family's past relationships, some recrimination against Ági regarding Eva, and personal agonizing.

It follows that the provenance of the diary is well documented, but the provenance of its contents less so. Ági had the diary for three years before publishing it, and several sources implied that Béla Zsolt's role might 
have exceeded that of a simple supervising editor.

The mother's emotional viewpoint is quite evident from the introduction, where she makes the allegation that Dr. Mengele personally threw Éva "into the oven". One also cannot help wondering about her choice of including the two aforementioned letters into the original publication. As for Béla Zsolt, he had a prominent writing and political career until 1949, when he died of illness, shortly after which Ági committed suicide, leaving a photograph of Éva lying next to her.

Much is known about Béla Zsolt and Ágnes Zsolt, and the diary provides more information about them than about other people involved in Éva's story, including Éva herself. Over the years, most critical evaluations of the diary were based on the Hebrew or English versions, but not on the Hungarian one, which was unavailable.

\section{Éva's Writing and Attitude}

Éva writes like an intelligent 13-year-old girl. She is sensitive to the conflicting family issues around her, does not ask questions, but rather turns the status quo into a form of acceptance and goes on with her life. Thus, even without the tremendous external strain imposed by the times, she has a great deal on her plate. Perhaps because of a tumultuous family life, she is able to observe with distant coolness how in a matter of two months her grandfather Rácz's pharmacy is taken over by a fascist Hungarian rival, and although bribes fail to get it back, in the end, for a short few weeks, a local government official returns ownership to Rácz, so that the town can have a functioning drugstore. When this situation changes abruptly and the drug store is again taken away, Éva takes it in stride, judging by her simple account of the events, with brief remarks, after which she moves on. Naturally, she has greater concerns and fears. She knows fairly well, although not exactly, that six months earlier her best friend, Márta, together with her family, was forcibly evacuated eastward (to Poland) and that she was likely murdered. Thus, the overriding theme in her diary is fear, specifically, fear of death. She states several times "I don't want to die", in a remarkably dignified tone. She also gives short shrift to various political tales she hears from the adults in the family and about the town, and muses over them, occasionally questioning events such as Admiral Miklos Horty's decision to parade into town on horseback about a year earlier. Horthy was the Hungarian head of state, and the incident was one in a series of showboating efforts by Hungarians to display their superiority over the Romanian population in Transylvania. Éva is quite aware of the subtle intricacies of national and ethnic rivalries, and quite cognizant of socioeconomic class divisions. There is an episode where she lists her many birthday gifts and alludes to the possibility that she is quite well off, but there are others who are even wealthier. So, in a way, she is a typical upper middle class Jewish teenager, having her first crush on a boy, and mostly content.

This contentment is shattered when the Germans enter the town in the middle of March. Her description of the suddenness and unexpectedness of these events closely parallels other historiographical sources, as well as primary documentation in many oral testimonies. Without notice, and under the forceful acts of the Gendarmerie - the feared Hungarian police force-property was taken, and during a week she was relocated several times. There are descriptions of hunger and scarcity; she describes the changes in comfort as their linens are taken away and the sudden lack of furniture. What stupefies her most is the almost hourly change in laws and decrees, something an experience in many Jewish communities throughout Europe. In these matters her words ring entirely true. From her last entry, of May 30, it is clear that Éva knows that they will be deported; she also plans to hand the diary over to Mariska for safekeeping. 


\section{Comparative Analysis of Matching Text}

For the analysis of the diary versions, this study compares the 1974 English edition with the 2011 Hungarian reprint, which is the exact duplicate of the first Hungarian version.

In general, two words that appear in the text with great frequency demand clarification. The most significant single unit in the text appears to be the word used to address an adult male in a casual conversation. The Hungarian language uses the word bácsi (pronounced bahchi), which has a rather common and simple connotation. In English, however, we find the word "uncle". This English word tends to convey a greater sense of familiarity, even in situations in which there is no family relationship to the person in question. In this case, such a verbal reference to any and all male figures may lead to confusion as to who is family and who is not, and even imply some manner of kinship, even if not by blood. In Hungarian, Éva's name for the diary, which she frequently addresses in the second person, is kis naplom. Literally, this means "my little diary". In the English version, "dear diary" is used. Although not literal equivalents, these two versions appear to be of comparable value.

Next, specific places and dates were mentioned in the diary in order to examine the context. The first entry is dated February 13, Éva's birthday. In this entry, she introduces and describes a few of the most significant characters in her life. There is also a general socioeconomic discussion of life in Nagyvárad, which is highly significant, because it demonstrates her maturity and social awareness. In broad terms, the topics include the role of Béla in her family life, together with her forced labor service in Ukraine, a discourse on legal issues involving the Nazi regime, and some economics-related matters used to position certain people on the socioeconomic scale. In addition, Juzsti, her governess, is introduced and described for the reader. Here one finds significant differences between the two versions. Although the content and facts are identical in the two version of the diary, the descriptions in Hungarian are rather simplistic, colloquial, without a clear-cut sense of hierarchy. In English, the descriptions are far more sophisticated and explanatory in nature. Here the reader gets a good sense of the economic and political order that prevails at the time.

In the March 16 entry, Éva discusses her grandfather Rácz and his pharmacy business, its economic aspects, ownership, and the relationship with the administration. The explanation concerns the fact that Grandfather Rácz is no longer allowed by law to own the pharmacy, but because of his skills, the current owner finds it necessary to employ him, at meager wages, in order to run the business properly. The sentences and expressions used in this entry demonstrate a level of explanation and degree of detail in English that are lacking in Hungarian. On page 48 (English), the following sentence can be read:

Let me point out that the commander of the city is also a Vitéz (family name, explanation by author): Vitéz Gábor Raynay, whose name used to be Rajner. At first I was happy, because I thought he was a Jew, since Jews used to change their names. (p. 48)

This is an extremely clear explanation of the circumstance at hand. The Hungarian text conveys the same information but in a limited and less precise fashion.

Finally, in the last entry, of May 30, in which panic and fear abound, at the very end, she mentions her intention to give her diary to Mariska for safekeeping. This is also the day when she first learns and uses the word deportation. This last entry shows entirely comparable degrees of distress and poignancy in both versions.

The conclusion derived from the comparison is that the content of the text remains the same, but the English reader gains a sense of accuracy that is lacking in the Hungarian text. Is this because of changes in 
sentence structure, of textual alterations, or simply because of the different nature of the two languages? Possibly because all of the above. The fact remains that an educated man, an author in his own right, created the translation, whereas the original is the creation of a child. Still, it is clear that the original text of the diary was altered in the course of the translation, but not in the printed Hungarian version, which attests to the immature use of language.

A word count analysis on one portion of the text was also conducted. For the February 13 entry, the word counts for the three versions are as follows: English, 2,179; Hebrew, 1,782; Hungarian, 1,765. These were compared to the word counts of Juzsti's letter, which is a non-diary text, with the following results: English, 2,046; Hebrew, 1,564; and Hungarian, 1,428. The word ratios for the diary are approximately $81 \%$ of Hebrew and Hungarian words of the total number of English words, and for the letter, $76 \%$ of Hebrew words and $70 \%$ of Hungarian words of the total number of English words. Both Hungarian and Hebrew texts are more laconic than English, and some degree of language induced variation may well enter the contextual framework.

\section{Conclusion and Discussion}

The most important contribution of the diary and of any subsequent discussion regarding its contents and versions is the expansion of Holocaust and post-Holocaust historiography. Although the examination of several versions of the diary reveals certain differences, most likely they are the product of language subtleties. Translations are normally performed by competent adult writers and do not usually reproduce a child's voice, unless specializing in children's texts.

The controversy regarding the authorship of the diary originated from the work by A. Zapruder, Salvaged Pages, and has been propagated by various websites, such as USHMM. The latter contains the following quotation: "There has been some doubt about the diary's authenticity... it could have been doctored by Éva's mother, who had the diary for more than three years before it was published" (Zapruder, 2002, p. 409). Accords Dr. Judah Márton (1988) responsibility for the explanation that there may be discrepancies from the original diary; but this claim is not properly substantiated examination of the various editions shows some propensity for inaccuracy and sensationalism arising from interjected images and cover jackets. Specifically, the 1988 version carries the following blurb on the back cover: "Éva Heyman was an extraordinary girl. Her last diary entry is dated May 30, 1944-only five months before Mengele himself pushed her to the crematorium in Auschwitz" (Márton, 1988). At the bottom of the same cover figures the Yad Vashem logo. That Yad Vashem should allow such a patently inaccurate statement to be associated with its name is quite astonishing.

Another issue relating to this diary, and all children's diaries for that matter, concerns the academic efforts to elevate the text into the realm of teachable and noble literature, which it is not. Zapruder (2002) quite correctly cautions against it. Indeed, such misplaced efforts have characterized the publication of children's Holocaust diaries for decades, the most notable example being Meyer Levin's total misappropriation of Anne Frank's diary, in order to pursue lofty goals. In the end, the diary of Éva Heyman, as any child's diary, should not serve "noble" purposes provisioned by academics and the public. These diaries are reflective of the tragic early end of murdered children.

\section{References}

Braham, R. L. (1994). The politics of genocide: The Holocaust in Hungary. Rev. and enl. (2ed ed.). East European monographs (Vol. 2). New York: Columbia University Press. 
Kádár, G., \& Zoltán, V. (2009). “Kasztner’s train.” Markman, Marsha Carow. 1996. "Teaching the holocaust through literature”. New Perspectives on the Holocaust, 147-158.

Marton, J. (1964). Jomanah šel Eva Heyman: The diary of Eva Heyman. Jad w-š̄m. Jerusalem: Yad Vashem.

Marton, J. (1974). The diary of Eva Heyman. M. Kohn (Ed.). (M. Kohn, Trans.). Jerusalem: Alpha Press and Yad Vashem Publications.

Marton, J. (1988). The diary of Eva Heyman (Original edition). New York: Shapolsky Publishers and Yad Vashem Publications.

Melnick, R. (1997). The stolen legacy of Anne Frank: Meyer Levin, Lillian Hellman, and the staging of the diary. New Haven: Yale University Press.

Reviczky, I. (1976). Deportation schedule nagyvarad. Retrieved from http://www.jewishgen.org/yizkor/oradea/oradea320.html

Shoah Resource Center. (2015). "Eva Heyman". Yad Vashem. Retrieved from http://www.yadvashem.org/odot_pdf/Microsoft

Word-3697.pdf

Tikvah. (2015). "A Nagvaradi Szidok Emletkonyve” Tikvah Association Oradea (Nagyvarad). Retrieved from http://www.jewishgen.org/yizkor/oradea/oradea.html

USHMM. (2015). Eva Lanyom. Retrieved February, 2015, from http://collections.ushmm.org/search/catalog/bib136997

USHMM. (2015). Eva Heyman. Retrieved 2015, from http://www.ushmm.org/wlc/en/idcard.php?ModuleId=10006554

Young, J. E. (1997). Between history and memory: The uncanny voices of historian and survivor. History and Memory, 47-58.

Young, J. E. (1988). Writing and rewriting the Holocaust: Narrative and the consequences of interpretation (Vol. 613). Bloomington: Indiana University Press.

Zapruder, A. (2002). Salvaged pages: Young writers' diaries of the Holocaust. Bloomington: Yale University Press.

Zsolt, Á. (1948). Eva Lanyom. Budapest: XXI. Szazad Kiado.

Zsolt, B. (1946). Kilenc koffe. Budapest: Magvető Könyvk. 